Cătălin CONSTANTINESCU

Faculty of Letters, „Alexandru Ioan Cuza” University

Iaşi, Romania

catalin.constantinescu@uaic.ro

\title{
FICTION MAY CONFRONT THEORIES. \\ LOCATING DETERMINISM OF THE NEWSPEAK IN G. ORWELL'S 1984
}

Recommended Citation: Constantinescu, Cătălin. "Fiction May Confront Theories. Locating Determinism of the Newspeak in G. Orwell's 1984". Metacritic Journal for Comparative Studies and Theory 7.2 (2021). Doi: https://doi.org/10.24193/mjcst.2021.12.14

\begin{abstract}
The paper focuses on the relationships between theory and practice and the consequences of dislocating theory from practice as they are illustrated through fiction. The case study carried out here concerns an exemplary novel, Ninety EightyFour by George Orwell, observing how the literary discourse can display a confrontation between two linguistic models, each resulted from a different theory: "instrumentalism" (Winston Smith) and "determinism" (O' Brien). Also, the possibility of identifying an Orwellian model as opposed to the Sapir-Whorf and the linguistic models deserves examination. Newspeak is full of problematic aspects: ideology shapes the language by means of "wooden language" (la langue de bois, in Françoise Thom's terms). Therefore, the historical "regime of relevance" (Galin Tihanov) makes possible a peculiar (use of) theory: an instrument that translates the ideology becomes the very essence of the determinist theory on the language in a totalitarian state. In discussing the practical consequences of literary theory, Stanley Fish points out that they are inexistent, because theory can never be united with practice, as it is actually impossible to separate theory from practice - a similar observation made by Steven Knapp and Walter B. Michaels. Whether consequences are real poses a challenge: following Edward Said's argument, Steven Mailloux observes that theory can be consequential by rhetorical means: theory does what all discursive practices do and that is that it attempts to persuade its readers (or
\end{abstract}


population in a totalitarian state) to adopt its point of view, its way of seeing texts and the world.

Keywords: determinism, instrumentalism, George Orwell, ideology, theory, practice

\section{The Premises of the Regime of Relevance}

According to Galin Tihanov, the rise and development of literary theory constitute the main condition in the shift from "monolithic" philosophical approaches around the time of World War I, in Eastern and Central Europe. Literary theory emerged as a conceptual by-product of the transition from a regime of relevance that focused on literature's role in social and political practice to "a regime that valued literature primarily for its intrinsic qualities as art" (Tihanov 22).

Nowadays it is largely accepted that literary theory is the product of a specific phase in the evolution of a particular regime of relevance. And a particular regime of relevance is a framework that has embedded the historicity of literary theory, as the latter is marked by radical historicity and is the product of a constellation of historical factors and parameters. These aspects influence and shape "the predominant understanding and use of literature for the duration of that particular constellation" (Tihanov 1), generating the regime of relevance. Different regimes of relevance are simultaneously available: instead of working in isolation, they are engaged in forms of exchange and competition and at any given moment, one of them becomes prominent and dominant, leading the debate on the specificity and the functions of literary discourse. For instance, modern literary theory "is the product of a regime of relevance that validates literature for its presumed artistic uniqueness and originality" (Tihanov 24).

Also, there is another regime of relevance which has gained increasing visibility in contemporary literary theory, namely a regime that:

has engendered an interpretative framework that has recently grown and gained enormous popularity, not least in the classroom, as "world literature". I put the words in quotation marks, not least because they usually refer to a particular liberal AngloSaxon discourse grounded in assumptions of mobility, transparency, and a recontextualizing (but also decontextualizing) circulation that supports the free consumption and unrestricted comparison of literary artefacts (Tihanov 175). 
To understand "world literature" and its location, a re-discussion of the issue of translation is needed. The current debate on "world literature" is partially seen as a legacy of the kind of literary theory that enacts again the cardinal debate about whether one should think literature within the horizon of language or beyond that horizon.

We must take into account both the singularity of language and its multiplicity. David Damrosch has confronted the tension between the two, concluding that studying a literary work in the languages of its socialization is more important than studying it in in the language of its production, as this approach restricts and undermines the methodological nationalism in literary studies.

Tihanov strongly believes that the regime of relevance in which literature is valued for its autonomy and uniqueness as a discourse that is unlike other discourses breaks with previous regimes of relevance, in which literature's significance was linked to its capacity to convey ideas, emotions, or knowledge of the world or to instigate socially and politically oriented actions (Tihanov 3 ).

Even if indirectly, through fiction, any reader may observe that Marxism - in twentieth century Russia - was the most resilient manifestation of a regime of relevance, hostile to recognizing the autonomy of literature and its presumed "literariness."

As for our case, one must keep in mind that literary theory is a historically circumscribed mode of thinking about literature.

\section{Theory vs Action. The Literary Text: A Strong Case}

In their seminal essay - a special project within literary criticism - Knapp and Michaels define theory as the attempt to "govern interpretations of particular texts by appealing to an account of interpretation in general” (Knapp and Michaels 723). They admit that sometimes this term is applied to literary elements belonging to narratology, stylistics, or prosody.

According to Knapp and Michaels, there are two major forms of contemporary theory: 1) theories which ground the reading of literary texts in methods designed to guarantee the objectivity and validity of interpretations (E.D. Hirsch considers that identifying meaning with the expression of intention is an objective method); 2) alternative theories that deny the possibility of a correct interpretation. 
Imagining the possibility of two different kinds of meaning - what is intended and what is actually meant, as John Searle separates them (222) - is more than a theoretical mistake: it is the sort of mistake "that makes theory possible" and "it makes theory possible because it creates the illusion of a choice between alternative methods of interpreting" (Knapp and Michaels 730). Stanley Fish argued that no general account of belief can have practical consequences, because he affirmed that a true account of belief must be a theory about belief (365), while Knapp and Michaels considered that a true account of belief can only be a belief about belief. Theory can have no practical consequences not because it can never be united with practice, but because it can never be separated from practice. This is valid for distinguishing meaning from intention, language from speech acts, knowledge from true belief, on an epistemological level.

For a better understanding of the tension between ideological thought and the ideological nature of language we should take into consideration the following observation: "A realist thinks that theory allows us to stand outside our beliefs in a neutral encounter with the objects of interpretation; an idealist thinks that theory stands outside our beliefs in a neutral encounter with our beliefs themselves" (Knapp and Michaels 739).

For a long time, a major concern was the persistent debate over the relation between authorial intention and the meaning of texts. Valid interpretations can only be obtained through an appeal to authorial intentions. But, as Knapp and Michaels point out, the project of grounding meaning in intention becomes incoherent. Actually, for Knapp and Michaels theory is nothing else than the attempt to escape practice (not another name for practice):

It is the name for all the ways people have tried to stand outside practice in order to govern practice from without. Our thesis has been that no one can reach a position outside practice, that theorists should stop trying, and that the theoretical enterprise should come to an end (742).

So, Knapp and Michaels argue in "Against Theory" that literary theory is unnecessary since a work's meaning is given by its intention to mean and this intention is inseparable from the language that expresses it, as Allen Thiher observed (337). 
In "Truth or Consequences: On Being against Theory", Steven Mailloux responds to Knapp and Michaels, providing some useful grounds for fiction as a positive and fruitful example in investigating the role of theory and practice. Mailloux emphasizes the role of ideological authority over the systems of beliefs and even over interpretation:

In George Orwell's 1984 the Party maintains its absolute power over the people of Oceania by completely controlling all individual acts of interpretation. Through material and ideological coercion, the Party imposes its way of making sense on its people and achieves "the persistence of a certain world-view and a certain way of life" which forms the basis of totalitarian rule (761).

These observations easily lead to one evident inference: "since the Party controls interpretation, it controls human consciousness and thus manipulates reality itself" (Mailloux 761).

Also, in Ninety Eighty-Four Orwell allows O'Brien to win the argument (both rhetorically and politically) during the final confrontation between him and Smith. O'Brien argues that reality exists only in the human mind, and nowhere else. Moreover, O'Brien maintains that whatever the Party holds to be true is true. Smith submits to the Party by internalizing its stance and adopts "its hermeneutic theory" (Mailloux 762).

The present study is consonant with Mailloux's analysis of the conflicting positions, as he accurately points out that while Smith holds that the nature of reality is self-evident, O'Brien demolishes this so-called naive realist ontology from his dominant political position through a form of idealism he calls collective solipsism:

You believe that reality is something objective, external, existing in its own right. You also believe that the nature of reality is self-evident. When you delude yourself into thinking that you see something, you assume that everyone else sees the same thing as you. But I tell you, Winston, that reality is not external. Reality exists in the human mind, and nowhere else. Not in the individual mind, which can make mistakes, and in any case soon perishes: only in the mind of the Party, which is collective and immortal. Whatever the Party holds to be the truth, is truth. It is impossible to see reality except by looking through the eyes of the Party (Orwell 118). 
Mailloux affirms that Knapp and Michaels would find neither Smith's realism nor O'Brien idealism to be satisfactory as a hermeneutics theory.

A realist like Smith is mistaken when he believes that an object exists independently of beliefs and that knowledge requires shedding one's beliefs in a disinterested quest for the object. He fails to understand that what he thinks are actual facts are as much a product of interpretation as are the Party's. Conversely, an idealist like O'Brien avoids Smith's error, assuming that "we can never shed our beliefs", but, as Mailloux demonstrates, he commits another error when he equates knowledge with the recognition of the fact that beliefs play a role in constituting their objects:

This constitutive hermeneutics is a necessary corollary of both O'Brien's collective solipsism and Fish's theory of interpretive communities. (...) O'Brien sees himself as the extension of an interpretive community (the Party) that completely dominates the world of 1984. Fish, on the other hand, claims that his world contains many competing communities, each vying for interpretive hegemony for its set of beliefs, values, and ideologies (762).

O'Brien affirms the alteration of this reality and the birth of a new one:

Do you begin to see, then, what kind of world we are creating? It is the exact opposite of the stupid hedonistic Utopias that the old reformers imagined. A world of fear and treachery is torment, a world of trampling and being trampled upon, a world which will grow not less but more merciless as it refines itself. Progress in our world will be progress towards more pain. The old civilizations claimed that they were founded on love or justice. Ours is founded upon hatred. (...) There will be no loyalty, except loyalty towards the Party. There will be no love, except the love of Big Brother. (...) When we are omnipotent we shall have no more need of science (Orwell 128).

This is somehow paradoxical, as the Party is omnipotent and its claims suggest that is has already abolished science - a statement that overlaps with the assumptions of the totalitarian discourses.

Knapp and Michaels argue that Stanley Fish makes a similar move when he claims to have a theory of interpretation (Knapp and Michaels 739) - a theory that allows him to argue that previous literary critics' "assumptions were not inferior but 
merely different" (Fish 368) from his own. Fish maintains here that "no beliefs are, in the long run, truer than others" (Knapp and Michaels 741). In effect, such point of view cannot exist outside belief, so he contradicts himself here. Theories like those of Fish and O'Brien, which admit the primacy of belief in practice, cannot just turn around and erase belief from theory. According to Mailloux, this is a case of prior separation of entities that are in fact logically inseparable (intention and meaning, language and speech acts, knowledge and true belief). If theory is understood as a description with prescriptive implications, consequences, then it is incoherent and should be abandoned. Proper theory has no consequences (Mailloux 763).

As Hannah Arendt in Origins of Totalitarianism and George Orwell in Ninety Eighty-Four demonstrate, this kind of theories does have consequences, due to the forceful tools of the Thought Police (thinkpol in the terms of Newspeak) and other propaganda institutions used by totalitarian states. Manipulation, terror, and torture have possible consequences on the "rewriting" of history and reality.

Edward Said (in Orientalism and other works) also demonstrates the disruptive consequences a theory can have, both inside and outside the discipline of literary studies: "through Orientalism Europe imposed a self-serving meaning in an apparently disinterested way. In effect, it created an Orient that was ripe for domination. The imperialist West did exactly what the Party in 1984 tries to do: determine reality by controlling interpretation" (Mailloux 764). The Party is simply more conscious about its own "hermeneutics of power." Mailloux observes that Said's theory resembles the epistemological idealism of O'Brien and Fish, who claim that shared beliefs (assumptions, values, ideologies) constitute reality. Assuming the position of Knapp and Michaels, no general account of belief has practical consequences. But, as Mailloux insists, "such accounts can and do have consequences. In the World of 1984, the theory of collective solipsism provides a philosophical base for totalitarian domination" (764).

The political consequences are only the most far-reached result of theory. In fact, theory is a kind of practice, a peculiar kind, because it claims to escape practice. The meanings it claims to find are actually determined by the beliefs it assumes. Theory is in effect "a set of operating instructions for the text itself so that it can produce a world through a kind of self-replication in language" (Thiher 341). In any way, this is the case of Ninety Eighty-Four by George Orwell. Alan Thiher is correct 
when asserting the analogy between a literary text and a theory devised as a formal system:

The analogy between a literary text or fiction and a recursively defined formal system puts the emphasis on the discovery of worlds that seemingly pre-exist the procedures that reveal them, yet which can only exist through these procedures. Recursive is used here in the mathematical sense of a repeated procedure (339).

Assuredly, this generates some patterns. Thiher concluded his text by encouraging us to use these types of analogies: "if all theory is a set of recursive rules that one plays with to produce models, then the analogy with myth and scientific procedures has certain fruitful plausibility" (350).

Using the suggested analogies, we may trace a line connecting several luminaries in literary history - as Thiher himself realized - when we carefully read George Orwell's fiction: Proust's A la recherche du temps presents a theory that applies to itself, describing the novel as the place for the recovery of an ontologically privileged moment; Kafka's work presents and becomes a negative description of the dysfunctional nature of the system; Borges' fictions mark the moment when the postmodern sense of literature as theory and theory as potential literature becomes clearly defined - his writings are "the best demonstrations of a series of theories or formalizations of the rules for the production of fiction that are in effect a replication of the theory that the fiction proposes" (Thiher 342).

Proust, Kafka, Joyce, Borges may constitute a historical series as "these are the essential names in one history that would lead to our contemporary understanding of literature as theory, of theory as literature, or the sense that fictions must propose the rules that underwrite their genesis at the same time as they produce fiction that is discovered within the rules of the game" (Thiher 345 ).

\section{Action as Discourse, Theory as Ideology. The Wooden Language and Its Consequences}

The processes of turning theory into action - the special case of manipulating theory when political power takes action - as seen in Orwell's Ninety Eighty-Four, unfold to analysis when the relationship between ideology and language is scrutinized. It is sure, one must be aware of the specific meanings of the term "ideology." 
Originally, it was coined by Antoin Destutt de Tracy, a French Enlightenment aristocrat and philosopher, who conceived it in 1796 as "the science of ideas" to develop a rational system of ideas in opposition to the irrational impulses of the mob. In political science the term is used in a descriptive sense to refer to political belief systems. Ideology may be political, epistemological, psychological, and sociological. For Françoise Thom, it has a special understanding: a kind of gnostic knowledge, establishing a doctrine of redemption, based on scientific assertions and pretensions. She refers to Marxism and Nazism as the highest embodiments of ideology.

It may sometimes be identified as a body of ideas reflecting the social needs of an individual, a group, a class, and a culture. Therefore, ideology refers to a systematic "world view" which defines our concepts of self and the relations of the self to the state or any form of collectivism. Briefly, ideology refers to belief systems and the principles within these systems, even if these "ideas" are unrecognized and thereby perhaps unquestioned.

One major step in describing the relationships between language and discourse and society was made by Françoise Thom's volume, La langue de bois (1987). The Communist discourse is perfectly "described" by the concise term wooden language (langue de bois). Françoise Thom maintains that Orwell was the first to understand that the official "language" of the '20s in the Soviet Union (the administrative usage of language - dubovîi iazik = oak tree language) and the "frozen language" from Poland are a new kind of language. Orwell observed that it is not a jargon, laughable and inoffensive, but the result of a shift issued at the intersection of language with ideology. Thom argues that Orwell had the intuition of the role played by Newspeak in the functioning of the totalitarian state.

The wooden language described by Françoise Thom has already been adopted in the Soviet Union of the "6os by a large part of intelligentsia, keeping up with the natural language. But from a historical perspective, Thom warns that one must keep in mind that wooden language was fully constituted by 1850 , when science replaces metaphysics as a preference of the Russian public.

The wooden language greatly differs from the authentic version of language: it pretends to be scientific discourse, excluding any kind of imaginary object, assuming to have exclusive control over the truth. It has only one function: to serve as a vehicle for ideology. 
Romanian historian Sorin Antohi added Françoise Thom's model to a system containing other three paradigms: 1) the Orwell model, as a paradigm of ideological models (the Communist use of language being the most prominent); 2) the SapirWhorf hypothesis, as a paradigm of cultural models; and 3) the linguistic model, as a sociolinguistic proposal that criticizes the other models. Sorin Antohi also adopted the suggestion made by Alexis de Tocqueville after 1831-1832, to see if there is any influence of the social state and the democratic institutions upon language itself.

For the purposes of the present study, our interest revolves around the Orwellian approach. As the need for accuracy is of the utmost importance, special attention will be given to two texts: "Politics and the English Language" (essay published in 1946 in Horizon magazine) and "The Principles of Newspeak," the Appendix of Ninety Eighty-Four (published in 1949). Orwell's essay on political language was based on his concerns regarding the decline of the English language, which is believed to have political and economic causes. He states that language becomes ugly and inaccurate, because our thoughts are foolish and that this process is reversible. Characterized by dying metaphors, operators or verbal false limbs, pretensions and meaningless words, language is strongly connected with the thinking process.

The novel Ninety Eighty-Four illustrates the hardcore version of the Orwellian thesis: political language may even determine political thought. Sorin Antohi identified the epistemological dilemma of the English author: it is too strong to be true and it is too weak to be false. As mentioned before, Orwell is - only apparently undecided between linguistic determinism (language does not describe reality, but mediates, interprets, and creates reality) and linguistic instrumentalism (language expresses pre-existent ideas, having a mimetic function). O'Brien is a determinist, assuming, in the name of the Party, that reality exists only in human mind, while Winston Smith maintains the mimetic function of the language. If language precedes thinking, therefore the Party controls minds and it can create any reality required by its ideology. This means the triumph of determinism, albeit a thesis that seems unconvincing to Antohi. Still, Orwell's main contribution remains indisputable: he opposes Oldspeak, the language spoken by workers, to a new language, Newspeak, spoken by the political elite, the members of the Inner Party. In fact, Orwell gave us the image of the language spoken by the political power elite in the form of the wooden language found in the Communist states. Analysing the refined 
interpretations of Françoise Thom, Czesław Miłosz, and Alain Besançon, Antohi observes that ,the goal of Newspeak was not to facilitate the articulation of a specific ideology, but to prevent heterodoxy through the planned shift in the linguistic system." 1

It is stated very clearly in the first paragraphs of the Appendix:

The purpose of Newspeak was not only to provide a medium of expression for the worldview and mental habits proper to the devotees of Ingsoc, but to make all other modes of thought impossible. It was intended that when Newspeak had been adopted once and for all and Oldspeak forgotten, a heretical thought that is, a thought diverging from the principles of Ingsoc should be literally unthinkable, at least so far as thought is dependent on words (Orwell 144).

As often as possible, wooden language - a result of the determinist urgency - avoids using precise verb forms and prefers the ambiguity of non-temporality, carefully masking the narration and underlining the immanent movement of things and acts. Wooden language avoids to refer to the moment of speech, to the circumstances of the discourse, to the speaker, exposing one of the main traces of the communist discourse: the absence of deictic words or expressions. "We" replaces "I" almost in every case, except for the official solemn discourses. Specifically, "we" means the unity of the people, the party, and the government. "We" is diametrically opposed to "them.” The discourse of O’Brien is highly illustrative:

Everything else we shall destroy everything. Already we are breaking down the habits of thought which have survived from before the Revolution. We have cut the links between child and parent, and between man and man, and between man and woman. No one dares trust a wife or a child or a friend any longer. But in the future there will be no wives and no friends. Children will be taken from their mothers at birth, as one takes eggs from a hen. The sex instinct will be eradicated. Procreation will be an annual formality like the renewal of a ration card. We shall abolish the orgasm. Our neurologists are at work upon it now. There will be no loyalty, except loyalty towards the Party. There will be no love, except the love of Big Brother. There will be no laughter, except the laugh of triumph over a defeated enemy. There will be no art, no

${ }^{1}$ My translation. In original: „scopul Newspeak-ului nu era atît să permită articularea unei anumite ideologii, ci să împiedice heterodoxia prin mutația planificată a sistemului lingvistic” (Antohi 143). 
literature, no science. When we are omnipotent we shall have no more need of science (Orwell 128).

The syntax, terminology, semantics of the wooden language are "raw-boned", being characterized by Manichaeism: progressist vs. reactionary.

The most important feature: to be efficient, the discourse must conform to a linguistic model, not to an idea, having a preference for quoting, instead of describing facts or expressing opinions. In the wooden language, the metalinguistic function is of primary importance, stressing tautological and pedagogical aspects.

The wooden language is a direct expression of a poor conceptual world, without being able to dislocate a notion, but being able to corrupt it, annexing the natural language and using the arbitrary sign, according to Thom. The suitability of the wooden language is a purely internal suitability, referring only to the mechanisms of the wooden language itself. This new language mimics the laws that it is describing, opting for an apparently scientific rhetoric by adopting the nominal style, being impersonal and distant from the natural spoken language.

In Ninety Eighty-Four Syme - the philologist from the Research Department - announces, in a dialogue with Winston Smith, the future of Newspeak: "in the end we shall make thoughtcrime literally impossible, because there will be no words in which to express it” (Orwell 24).

Without the wooden language, society would counteract the aggression of the ideology with a complex network of traditions, human relationships, and mutual agreements. The communist discourse turns language into something arbitrary and manages to discredit language itself, stripping away any last trace of humanity in man.

As Hannah Arendt indicates, the peculiarity of totalitarian propaganda closely linked with wooden language - resides in its false scientific character, marked by the "almost exclusive insistence on scientific prophecy as distinguished from the more old-fashioned appeal to the past” (345).

The wooden language does not communicate new ideas. This language is highly useful for the Communist party and for the totalitarian state, supporting the continuity of the ideological fiction. Without permanent readjustment and update, ideology loses its virulence and impact on the world. Hannah Arendt emphasizes the scientific falsehood present in this totalitarian persuasive discourse: 
Totalitarian propaganda raised ideological scientificality and its technique of making statements in the form of predictions to a height of efficiency of method and absurdity of content because, demagogically speaking, there is hardly a better way to avoid discussion than by releasing an argument from the control of the present and by saying that only the future can reveal its merits (346).

The whole discourse is challenged by the task of destroying reality, because the final goal is to substitute it by a "Marxist-Leninist reality." The tactics were also thoroughly noted by Françoise Thom: occultation, transformation and diversion.

The co-substantiality of the wooden language and ideology becomes evident based on similarities between the mechanism of the wooden language and the norm proclaimed by the Communists.

Thom affirms that the language that ignores and despises reality has nothing in common with the discourse of propaganda. Strictly speaking, it is a political language above all. A model was formulated by the Soviet author N.J. Marr (Iazîk $i$ misșlenie), who proposes the universal language of the future, including two main traces of ideology: hatred toward nature and the refusal of mediation. Stalin opposed to Marr (see L.L. Thomas, The Linguistic Theories of N. Marr, 1957) as ideologist, since he believed that language must be subordinated to ideology.

Wooden language does not legitimate power, as it contributes to the functioning of the Communist state, seizing the whole society. Due to the wooden language, power is built on ideology in order to diffuse it in society. Its function is double: to refract and amplify the ideological power, on the one hand, and on the other hand, to impose the ideological power within that particular society.

Wooden language must permanently portray political power; it has to demonstrate that it is arbitrary and unlimited and it does this in two ways: exposing the evidence and strongly contradicting itself. Also, arrogant affirmation and the reification of power represent a constant function of wooden language. Any citizen who is subject to the wooden language finds himself in the position of the detainee: truth is disregarded in the official discourse (that he must absorb and reproduce/use).

Through the wooden language, Communist authorities can openly proclaim that slavery is happiness, famine is prosperity, war is love - and nobody will rise up against it. Ideology, through the wooden language, transforms the world into 
language, as wooden language replaces phenomena and facts with tropes. The dialectical mechanism is a paradigm of the wooden language.

Ideology has no power against reality, but it can certainly destroy it; for this reason, ideology must find other forms of manifestation. Wooden language fights a triple battle: 1) against facts, 2) against the past, 3) against people. Through wooden language, ideological power becomes a phenomenon, while ideology itself is only nothingness, non-being (Thom 141). For sure, as Orwell's novel shows, the wooden language simultaneously eliminates memory and the sense of identity.

The control over reality is possible by doublethink in Ninety Eighty-Four:

To know and not to know, to be conscious of complete truthfulness while telling carefully constructed lies, to hold simultaneously two opinions which cancelled out, knowing them to be contradictory and believing in both of them, to use logic against logic, to repudiate morality while laying claim to it, to believe that democracy was impossible and that the Party was the guardian of democracy, to forget whatever it was necessary to forget, then to draw it back into memory again at the moment when it was needed, and then promptly to forget it again: and above all, to apply the same process to the process itself. That was the ultimate subtlety: consciously to induce unconsciousness, and then, once again, to become unconscious of the act of hypnosis you had just performed. Even to understand the word «doublethink» involved the use of doublethink (Orwell 16).

There is no doubt that the wooden language is the central tool of the totalitarian state. Arendt argues that in such states propaganda and terror are two facets of the same coin:

The success of totalitarian propaganda, however, does not rest so much on its demagoguery as on the knowledge that interest as a collective force can be felt only where stable social bodies provide the necessary transmission belts between the individual and the group; no effective propaganda based on mere interest can be carried on among masses whose chief characteristic is that they belong to no social or political body, and who therefore present a veritable chaos of individual interests (348).

But this is only partially true. Terror is a form of the government pertaining to totalitarianism: 
Propaganda is indeed part and parcel of "psychological warfare"; but terror is more. Terror continues to be used by totalitarian regimes even when its psychological aims are achieved: its real horror is that it reigns over a completely subdued population. (...) Propaganda, in other words, is one, and possibly the most important, instrument of totalitarianism for dealing with the nontotalitarian world; terror, on the contrary, is the very essence of its form of government (Arendt 344).

It is known that when Stalin decided to "rewrite" the history of the Russian Revolution, the propaganda of his new version consisted in destroying the authors altogether with their old documents and books: "the publication in 1938 of a new official history of the Communist Party was the signal that the superpurge which had decimated a whole generation of Soviet intellectuals had come to an end" (Arendt $342)$.

The rewriting of history is undoubtedly one of the main traces of totalitarian ideology, as identified by Orwell, too:

But to trace out the history of the whole period, to say who was fighting whom at any given moment, would have been utterly impossible, since no written record, and no spoken word, ever made mention of any other alignment than the existing one. At this moment, for example, in 1984 (if it was 1984), Oceania was at war with Eurasia and in alliance with Eastasia. In no public or private utterance was it ever admitted that the three powers had at any time been grouped along different lines. Actually, as Winston well knew, it was only four years since Oceania had been at war with Eastasia and in alliance with Eurasia. But that was merely a piece of furtive knowledge which he happened to possess because his memory was not satisfactorily under control (14).

Propaganda is one of the most important, and perhaps the most important, tools of totalitarianism to face the non-totalitarian world. But one must always keep in mind its main end: "The true goal of totalitarian propaganda is not persuasion but organization" (Arendt 361). Hannah Arendt defines totalitarian regimes by recognizing the role of ideology in the instigation and perpetuation of totalitarianism.

The title of the present paper may be considered misleading, as my hypothesis is that fiction does not necessarily confront theory, but it enables the creation of a space where the two are confronted. Ninety Eighty-Four by George Orwell makes such a space where instrumentalism (Winston Smith) encounters determinism 
(O'Brien). Orwell's fiction permits a theoretical debate on the nature of language, as it gives us a framework for theorizing the wooden language. Still, where we might be wrong is if we treat ideology as theory. Mainly, the last chapter of Ninety Eighty-Four is relevant in this sense, focusing on the torture episode: the whole process of the torture illustrates a confrontation, but at the same time it shows that theory and practice have certain consequences, as Steven Mailloux and Edward Said convincingly demonstrate.

Theory always describes a phenomenon. In our case such a phenomenon might be called "ideological language", controlling and influencing the "ideological reality." Under such circumstances, to read Orwell means to identify theory in practice. Not literary theory, but a theoretical model for understanding the nature of language in contact with the reality of thinking.

\section{References:}

Antohi, Sorin. Exercițiul distanței. Discursuri, societăți, modele. Nemira, 1997.

Arendt, Hannah. The Origins of Totalitarianism. Harcourt Brace \& Co., 1979.

Fish, Stanley. Is There a Text in This Class? The Authority of Interpretive Communities. Harvard University Press, 1980.

Knapp, Steven, and Walter Benn Michaels. "Against Theory." Critical Inquiry, vol. 8, no. 4, summer 1982: 723-742.

Mailloux, Steven. "Truth or Consequences: On Being against Theory." Critical Inquiry, vol. 9, no. 4, June 1983: 760-766.

Orwell, George. Ninety Eighty-Four. E-text. London: Penguin Books UK, 2000.

Searle, John. "Reiterating the Differences: A Reply to Derrida." Glyph, vol. 1, 1977: 198-208.

Thiher, Allen. "A Theory of Literature or Recent Literature as Theory." Contemporary Literature, special issue o Contemporary Literature and Contemporary Theory, vol. 29, no. 3, autumn 1988: 337-350.

Thom, Françoise. Limba de lemn. Translated by Mona Antohi, second edition, Humanitas, 2005.

Tihanov, Galin. The Birth and Death of Literary Theory. Regimes of Relevance in Russia and Beyond. Stanford University Press, 2019. 